\section{Detecting mistletoe infestation on Silver fir using hyperspectral images}

\author{
Mario Ančić (1), Renata Pernar ${ }^{(1)}$, Milan Bajić ${ }^{(2)}$, Ante Seletković ${ }^{(1)}$, \\ Jelena Kolić ${ }^{(1)}$
}

Silver fir is one of the most important commercial and ecological species in Croatia, and is currently the most damaged tree species in Croatian forests. It is increasingly infested by white mistletoe, whose relevant consumption of water and nutrients contributes to physiological weakening of the tree. Early mapping of mistletoe infestation based on remote-sensed methods may overtake current limitations of standard field methods and their high costs in the assessment of tree health over large areas. The main goal of this study was to develop an efficient and reliable method for mistletoe detection based on hyperspectral images and supervised classification methods. Surveying was performed in a mountain area of Croatia characterized by beech-fir forests using a hyperspectral scanner. The Spectral Angle Mapper (SAM) classification with $5^{\circ}$ threshold value proved to be the best classification method. The first "spectral signatures" - endmembers for fir and mistletoe, were determined and entered into a spectral library database. Using the above approach, a reliable picture of the spatial distribution of mistletoe-infected silver fir trees over the whole studied area was obtained. Results were validated by aerial surveying with a non-pilot aircraft from $\sim 30 \mathrm{~m}$ above the crowns. The approach used here may allow a cost-effective mapping of the distribution and intensity of mistletoe infection in silver fir, and can be considered an helpful tool for forest management and planning, forest protection and harvesting.

Keywords: Remote Sensing, Hyperspectral Images, Spectral Signatures, Mistletoe Detection, Health Status, Silver Fir

\section{Introduction}

The narrow ecological niche and the extensive exposure to pollution makes silver fir (Abies alba Mill.) a highly endangered species. It is currently the most damaged tree species in Croatian forests (Prpić \& Seletković 2001, Potočić et al. 2008). In addition to insects and fungi, fir is increasingly attacked by mistletoe (Viscum album L. ssp. abietis [Weisb.] Abrom), which physiologically weakens the tree by its remarkable consumption of water (Fisher 1983, Lamont 1983, Ehleringer et al. 1986) and mineral nutrients (Watson 2001), thus predisposing the host to pest and disease attacks. Mistletoe is also considered an indicator of existing stress (Atzberger \& Werner 1998, Smith et al. 2004, Moorthy et al. 2008, Wang \& Li 2012). It has been reported that an excessive

number of shrubs may even cause tree death (Plagnat \& Brossier 1969, Cervera \& Villaescusa 1977, Zuber 1983, Chéret et al. 1987, Tsopelas et al. 2004, Olivia \& Colinas 2007). Morevover, mistletoe-infected trees have lower increment than uninfected trees (Klepac 1955, Uščuplić 1992, Uščuplić \& Dautbašić 1998, Noetzli et al. 2003, Barbu 2009) and should therefore have a cutting priority as long as their timber still retains its commercial value.

A high correlation between fir infestation and mistletoe distribution has been reported (Hofstetter 1988, Idžojtić et al. 2008, Barbu 2009) with an almost exponential trend in the mistletoe population increase (Noetzli et al. 2003). An increase in the intensity of mistletoe infestation was also noted, favoring its spread to healthy trees (Idžojtić et al.

$\square$ (1) Faculty of Forestry University of Zagreb, Svetošimunska cesta 25, 10000 Zagreb (Croatia); (2) Faculty of Geodesy University of Zagreb, Kačićeva 26, 10000 Zagreb (Croatia)

@ Mario Ančić (ancic@sumfak.hr)

Received: May 07, 2013 - Accepted: Oct 31, 2013

Citation: Ančić M, Pernar R, Bajić M, Seletković A, Kolić J, 2014. Detecting mistletoe infestation on Silver fir using hyperspectral images. iForest 7: 85-91 [online 2013-12-18] URL: http://www.sisef.it/iforest/contents/?id=ifor1035-006

Communicated by: Alberto Santini
2003). Tree health status can be determined in two ways: by ground and by remote sensing observations, of which color infrared (CIR) images are particularly important (Pernar 1997, Pernar et al. 2007a). In Croatia, forest damage over large areas has been assessed by means of CIR aerial imagery since 1988, though mistletoe could not be detected based on these images. Preliminary pilot tests aimed at assessing fir damage using multispectral digital images have been carried out in 2004 (Pernar et al. 2007b), confirming that mistletoe could be successfully detected using a high-resolution multispectral digital camera. In contrast, standard field methods for mistletoe detection are generally based on visual survey (using binoculars) of edge trees along roads or in clearings, from which only the upper crown is visible (Idžojtić et al. 2005), and therefore do not often reflect the real conditions in the field. For example, Diminić et al. (2011) suggests that ground analyses of mistletoe presence in the crowns of standing trees are not fully reliable.

The limitations of standard field methods call for new approaches to assess tree health and quantify mistletoe infestation. The importance and efficiency of high-resolution multispectral and hyperspectral imagery for the goals mentioned above have been highlighted by Entcheva-Campbell et al. (2004), Somers et al. (2010) and Cho et al. (2012). By recording a high number of narrow bands and increasing the spectral resolution, hyperspectral images make it possible to discern very narrow spectral features (Aspinall et al. 2002, Shaw \& Manolakis 2002). Hyperspectral research in Croatia was launched within the Croatian mine action center (CROMAC) programme focused on the reduction of mine-polluted areas in Croatia (CROMAC ARC team 2002, Bajić et al. 2008). A line hyperspectral scanner provided the first reflectance curves of fir and mistletoe, which were used as entry parameters for further research (Pernar et al. 2007a, 2007b).

The aim of this research was to develop an efficient and reliable method of mistletoe detection over large areas using a hyperspectral scanner and supervised classification methods.

\section{Materials and methods}

Hyperspectral scanning was performed in two areas characterized by the presence of beech-fir forests in the Dinaric region of Croatia (Lipovlje: $44^{\circ} 50^{\prime} \mathrm{N}, 15^{\circ} 11^{\prime} \mathrm{E}$; Ramljani: $44^{\circ} 44^{\prime} \mathrm{N}, 15^{\circ} 23^{\prime} \mathrm{E}$ ). At the time of aerial survey (April), deciduous species had not yet burst into leaves. Data collected with a hyperspectral line scanner ImSpector V9 (spectral range 430-900 nm, spectral resolution $7 \mathrm{~nm}$ ) mounted on an helicopter were recorded as individual lines, together 
Fig. 1 - 3D image of the hyperspectral cube in TNTmips Free $^{\mathbb{B}}$, wavelength $0.610 \mu \mathrm{m}$.

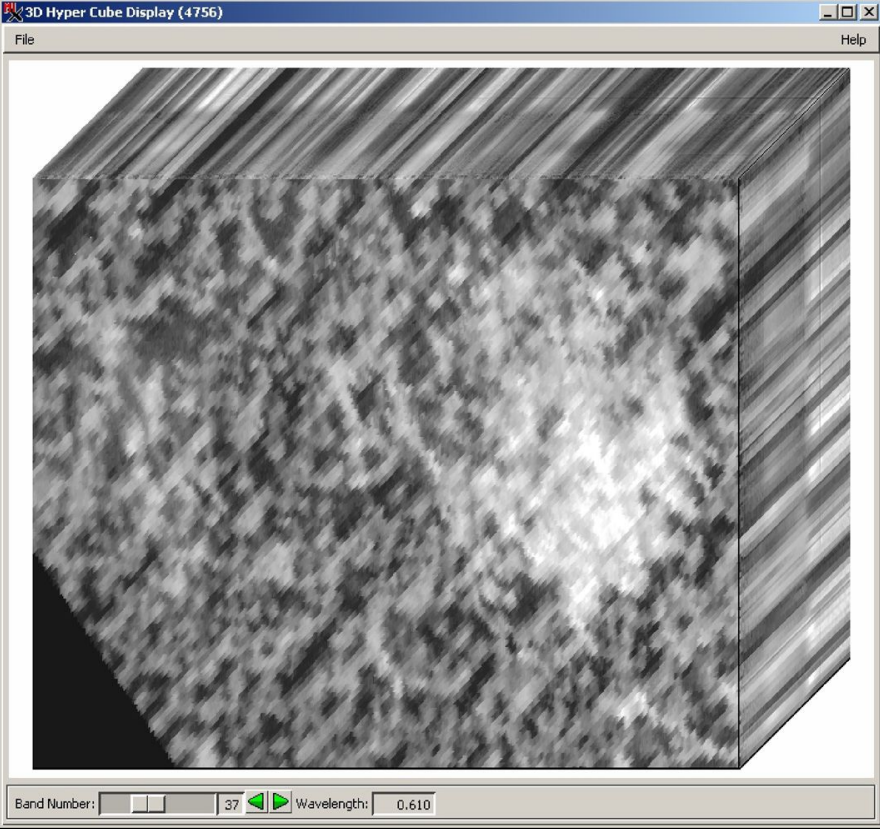

with spatial data from the Position and Orientation System (POS). These data were used to conduct parametric geocoding and obtain a raw geocoded hyperspectral cube (Fig. 1). After formulating the real geocoded hyperspectral cube, an image similar to a color infrared was obtained by selecting the following bands: $94(895 \mathrm{~nm}$, the near infrared part of the spectrum); $54(695 \mathrm{~nm}$, the red part of the visible spectrum); 22 (535 $\mathrm{nm}$, the green part of the visible spectrum). Hyperspectral scanning provided pure spectral samples (endmembers), and showed a difference between the spectral curves of fir and mistletoe. The spectral samples formed a part of the spectral booklet created by means of the TNTmips Free ${ }^{\circledR}$ Hyperspectral module. The booklet served as a basis for interpreting the data collected by aerial surveys over large areas. Samples according to three classes (vegetation, shadow, and rock) were taken from the whole area. These samples differ not only visually but also in terms of spectral curves. Based on the collected
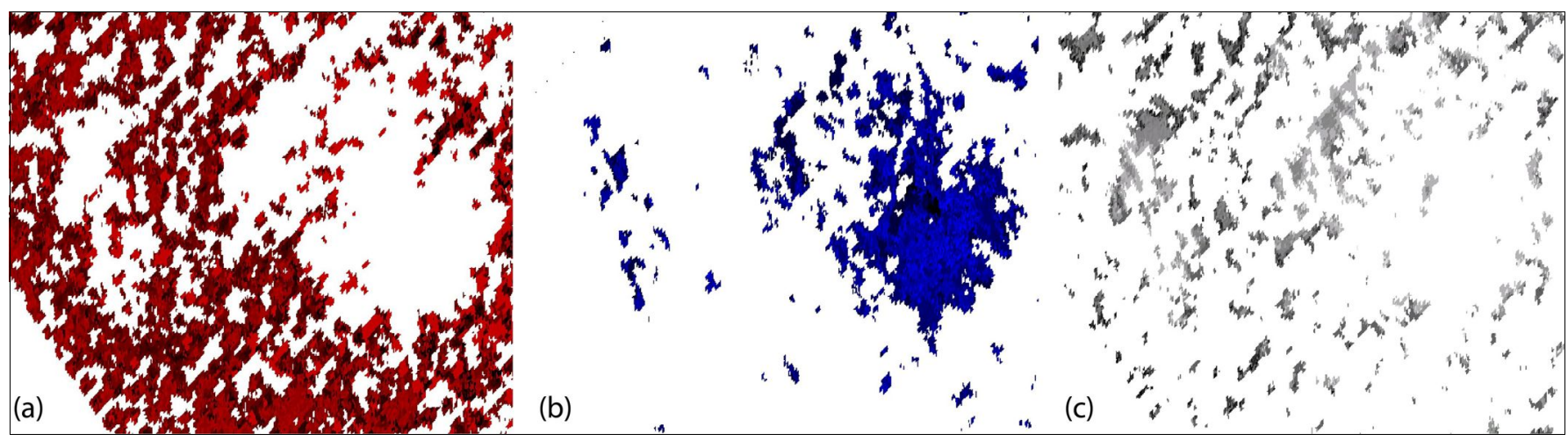

Fig. 2 - Result of the application of the SAM classification method with $7^{\circ}$ threshold value for (a) vegetation, (b) rock and (c) shadows.

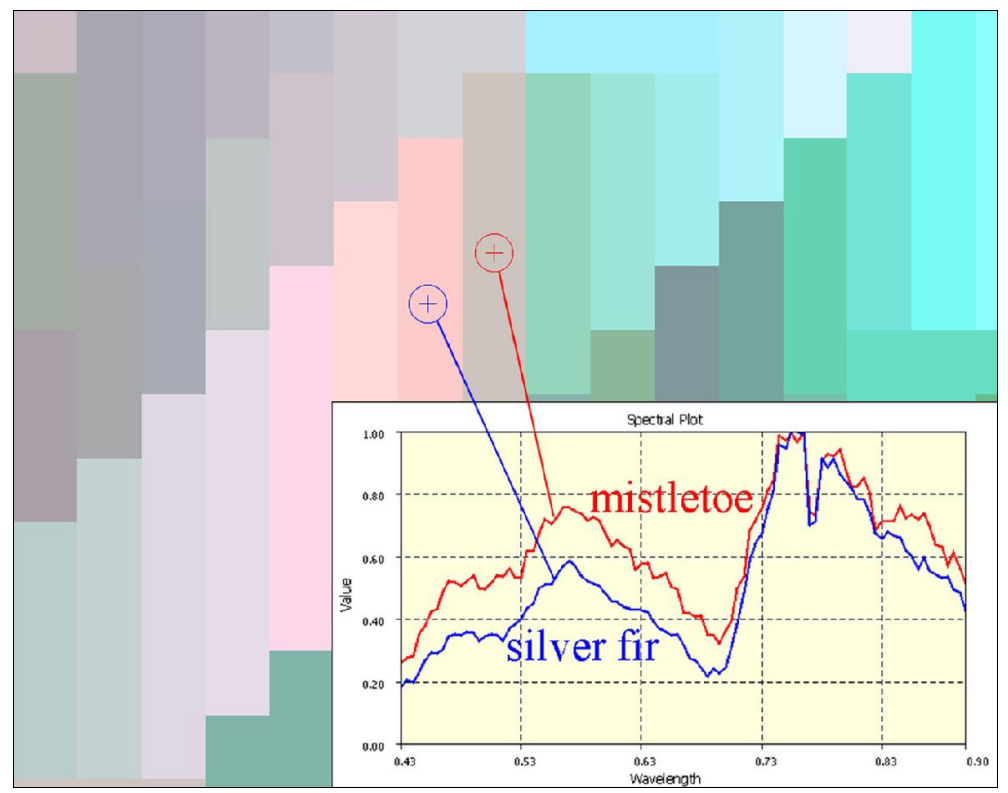

Fig. 3 - Comparison of mistletoe and fir spectra in the magnified part. samples, the following supervised classifications were conducted: Feature Mapping, Hyperspectral analysis (Spectral Angle Mapper - SAM, Cross-correlation, Linear Unmixing, Fuzzy C means), as well as an unsupervised Fuzzy C means classification. Satisfactory results were obtained using SAM and Crosscorrelation, of which the SAM method was the best (Fig. 2). The SAM algorithm is an easy and rapid method for mapping the similarity of image spectra to reference spectra. It is also a very powerful classification method because it holds back the influence of shading effects and enhances the target reflectance characteristics (De Carvalho \& Meneses 2000, Girouard et al. 2004). The reference spectra can either be taken from laboratory or field measurements or extracted directly from the image. SAM measures the spectral similarity by calculating the angle between the two spectra treating them as vectors in a $n$-dimensional space (Kruse et al. 1993, Van der Meer et al. 1997, Rowan 
\& Mars 2003, Girouard et al. 2004). Small angles between the two spectra indicate high similarity, while large angles indicate low similarity. A supervised classification procedure was conducted for the selected areas in the vegetation class in order to delineate the spectral curves for fir and mistletoe. Pixels differing from their neighbors (surrounding pixels) based on the shape of their spectral curve were selected in the supervised classification process (Fig. 3). The spectral curve of the selected pixels followed the shape of the reference spectral curve for mistletoe obtained by scanning under controlled conditions (Fig. 4). The procedures of selecting the class of mistletoe and testing within the same class included the selection of the samples for SAM classification separately with $4^{\circ}, 5^{\circ}$ and $6^{\circ}$ of threshold value (degrees were selected by testing). The arithmetic means were calculated separately for each threshold. As the degrees within the SAM classification increased, the number of the selected samples also increased, but a shift also occurred in the spectral curves of the selected mistletoe samples with $4^{\circ}, 5^{\circ}$ and $6^{\circ}$ thresholds. The largest difference occurred in the near infrared part of the spectrum, which showed a downward tendency towards the fir spectrum, whereas the spectral curves in the visible and "Red Edge" part of the spectrum retained their shape and exhibited only very slight fluctuations. The selected curves of the arithmetic means for $4^{\circ}, 5^{\circ}$ and $6^{\circ}$ SAM classifications were compared each other and with the spectral curves obtained for fir (Fig. 5). After the mistletoe samples were selected and SAM classifications performed, a SAM classification within the vegetation class was carried out using pure spectral samples (endmembers) for fir and mistletoe as reference. Comparison for all estimations was performed using a repeated measures analysis of variance (ANOVA) with $\alpha=0.05$ using the package Statistica 7.1 ${ }^{\circledR}$ (StatSoft 2006).

The SAM classification procedure with threshold value $5^{\circ}$, which proved to be optimal, was performed over all the image segments. In order to test for any major changes in solar irradiation during hyperspectral scanning data collection, mean values of insolation were calculated based on data recorded by FODIS. Spectral ranges where large portions of electromagnetic radiation are absorbed by the atmosphere (atmospheric maxima) were excluded from data processing to avoid spurious results in the spectrum values.

Moreover, in order to verify the impact of the relief on vegetation classification results, a digital elevation model was constructed. Three directions (north-south - NS, the flight direction - DF, and orthogonal to the flight direction - ODF) were considered (Fig. 6), each including two sub-categories (before

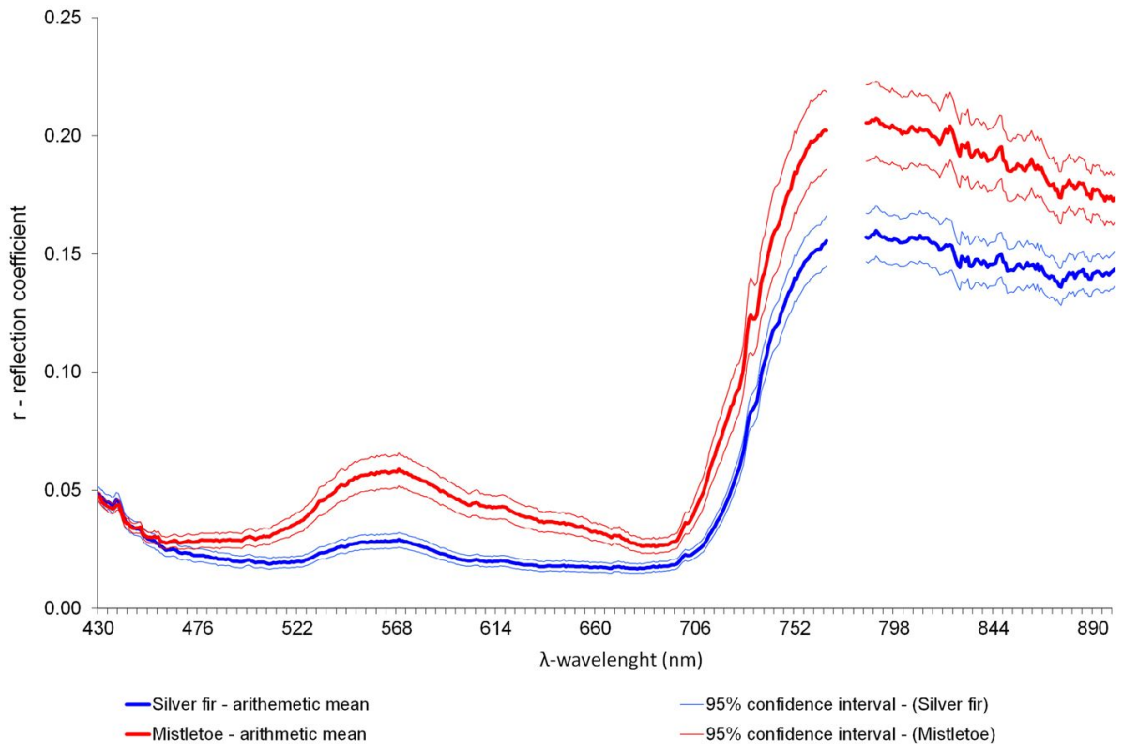

Fig. 4 - Mean values of spectral reflectance for silver fir and mistletoe over the wavelength range considered in this study.

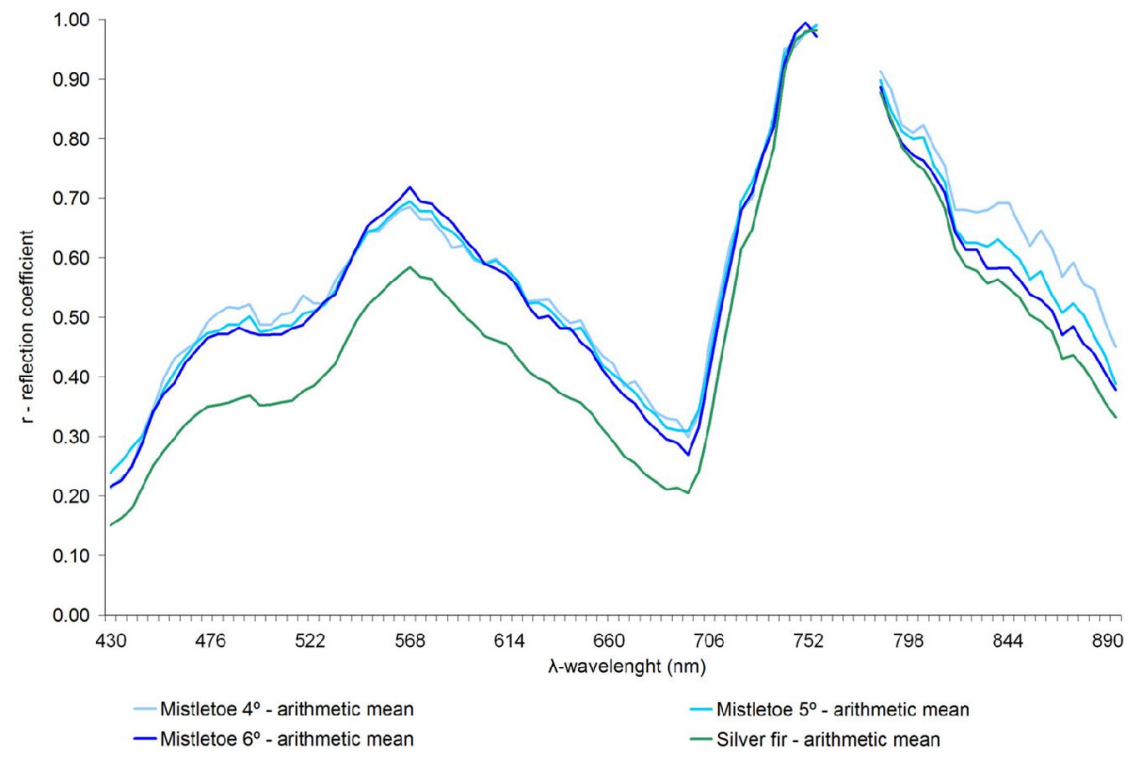

Fig. 5 - Comparison of arithmetic mean values of reflectance for mistletoe (using SAM classification with threshold $4^{\circ}, 5^{\circ}$ and $6^{\circ}$ ) with mean values obtained for silver fir (green line).

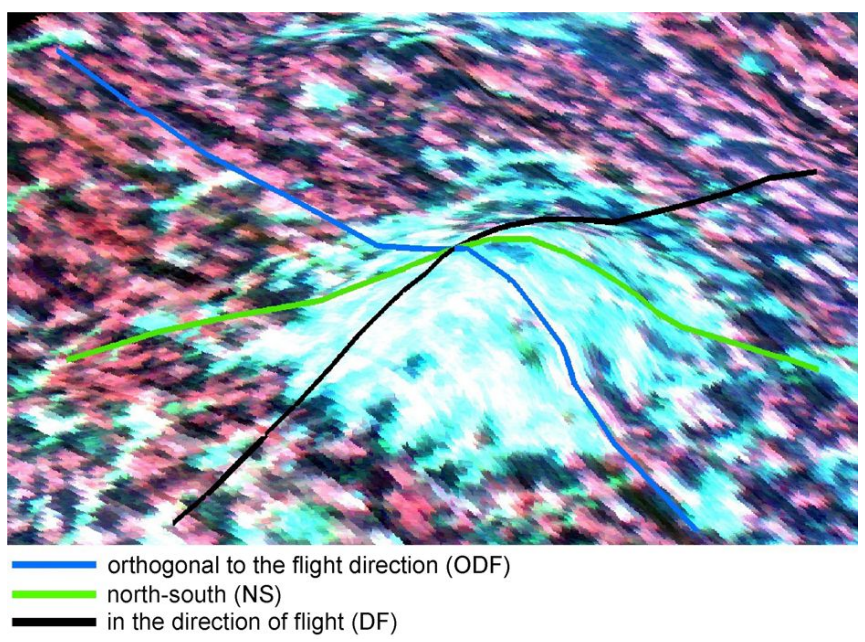

Fig. 6 - Flight directions for which vegetation spectrum values were measured. 


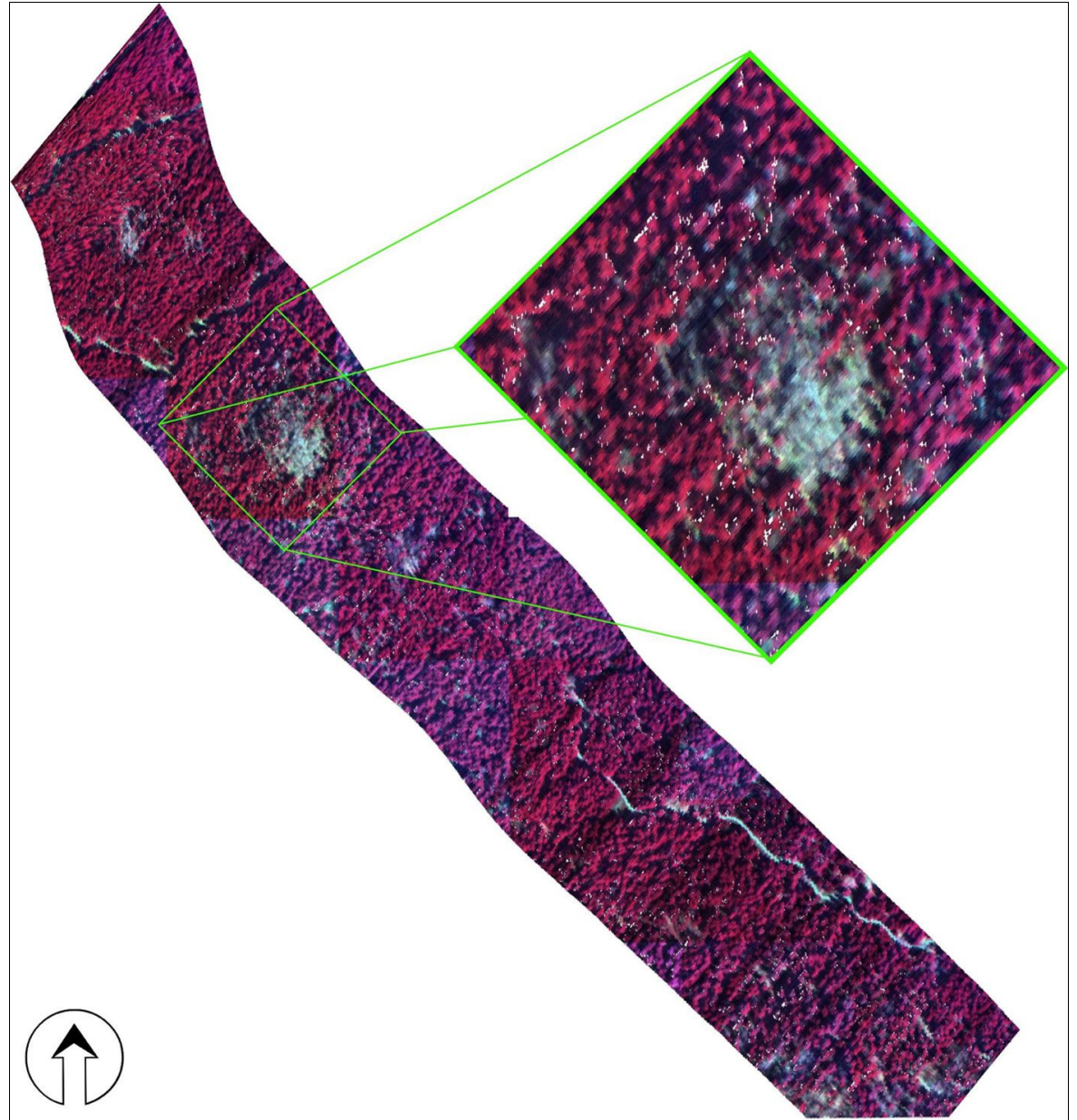

Fig. 7 - Results of the SAM classification using endmembers (pure spectral samples) as reference for mistletoe (white pixels).

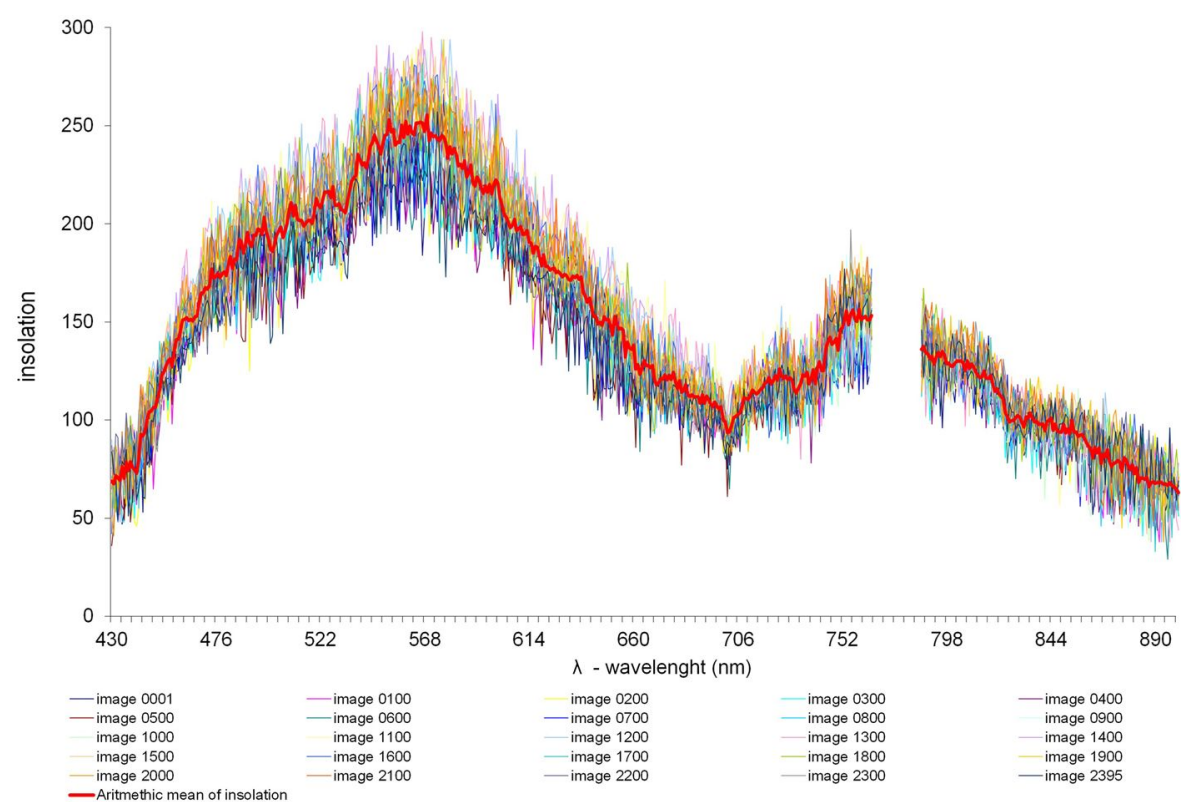

Fig. 8 - Graphic representation of measured insolation (solar irradiation) values and its arithmetic mean (red line) across the analyzed spectral range (430-809 nm). hill and after hill). Results were verified by aerial recording with an unmanned aircraft (hexacopter), for which all flight parameters were recorded (position, height, direction, speed, etc). Survey was performed at several flight altitudes above the crowns $(\sim 30 \mathrm{~m}$, $\sim 50 \mathrm{~m}, \sim 70 \mathrm{~m}$ ).

\section{Results and discussion}

Of the applied methods of supervised (Cross correlation, SAM, Fuzzy C means, Feature Mapping) and unsupervised (Autoclassify) classifications, satisfactory results were obtained using both Cross correlation and SAM methods, though the latter proved to be the best. Based on the mistletoe samples identified using SAM classification, it was possible to detect and select mistletoe bushes within the fir crown. However, a high variability was observed in the data collected, as reflected in the misclassification of a part of the overlaying selected pixels as fir classes obtained by automatic classification methods. This could be due to the partially overlapping spectral curves obtained for fir, not clearly differentiated as the spectral curve for mistletoe.

Using the SAM method with $4^{\circ}, 5^{\circ}$ and $6^{\circ}$ threshold values in the selected samples within the mistletoe class, mean values of spectral curves for the mistletoe were obtained, clearly distinct from the fir spectrum for all the tested degrees. By increasing the degree, a partial overlap of the near infrared part of the spectrum was observed in the reflectance curves for mistletoe and silver fir. This implies that for threshold degrees higher than $6^{\circ}$ fir would be discerned instead of mistletoe (Fig. 5).

The final outcome of the investigation carried out was the identification of the spatial distribution of mistletoe-infected silver fir trees over the whole studied area (Fig. 7). The results of testing the effects of insolation on classification outcomes are presented graphically in Fig. 8, after subtraction of maximum absorbance values. As expected, insolation varied during scanning, though no abrupt leaps or large fluctuations were observed around the central values. Therefore, we concluded that insolation did not affect the classification obtained.

The impact of the relief on the classification obtained was assessed by comparing reflectance values measured in the different directions (NS, DF, ODF - see Fig. 6). The largest deviation was found for the NS direction in the visible part of the spectrum, up to the "Red Edge" area (430-700 $\mathrm{nm})$, and again from the center of the near infrared area to the end of the spectrum (835-900 $\mathrm{nm})$. In the visible part of the spectrum, differentiation in the blue $(455-475 \mathrm{~nm})$, cyan $(476-495 \mathrm{~nm})$ and green $(496-535 \mathrm{~nm})$ are particularly conspicuous (Fig. 9a). Comparison of values for the three measuring direc- 

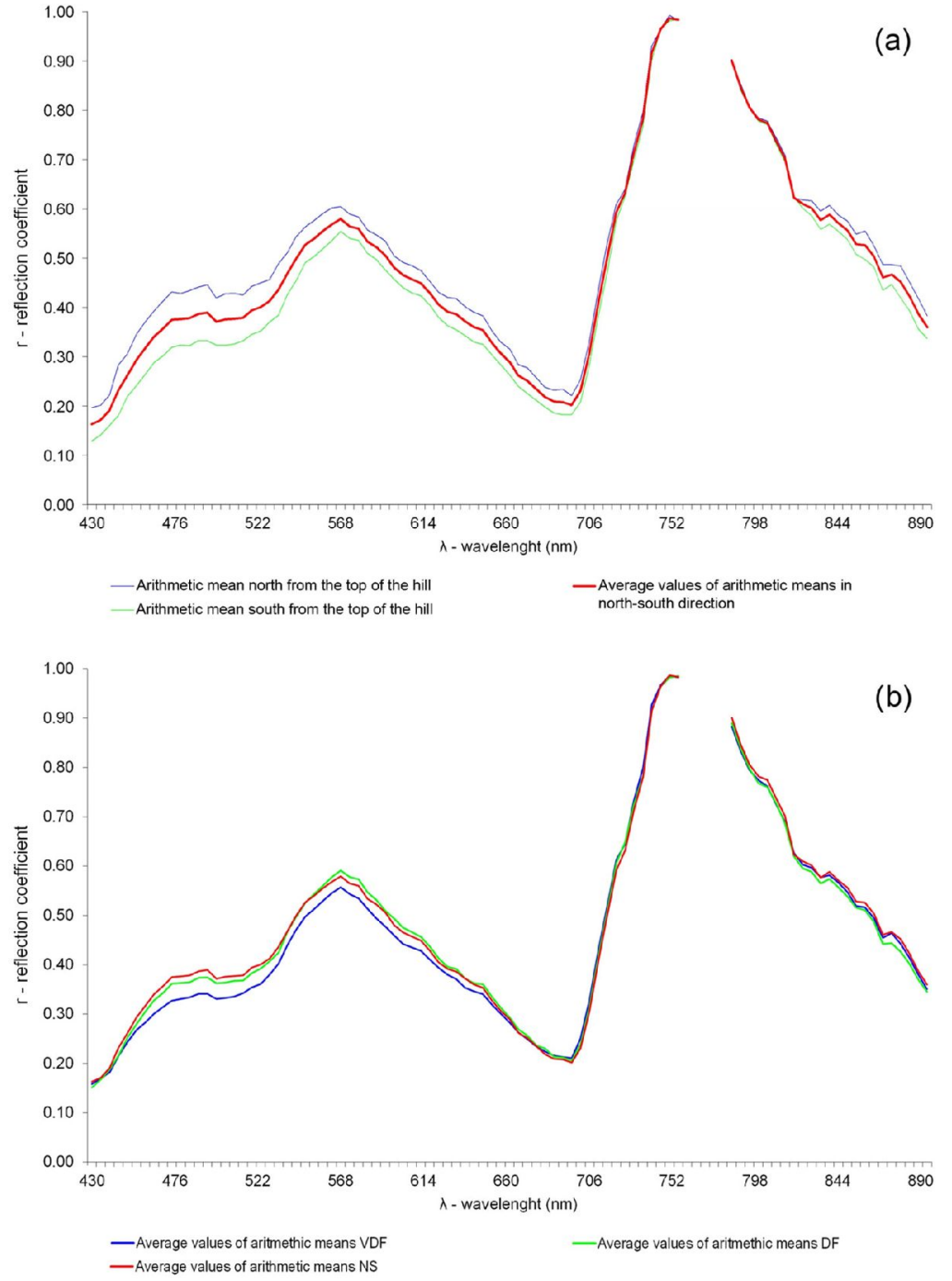

Fig. 9 - Comparison among arithmetic means and their mean values in NS direction (a) and comparison of arithmetic means by measuring directions (b).

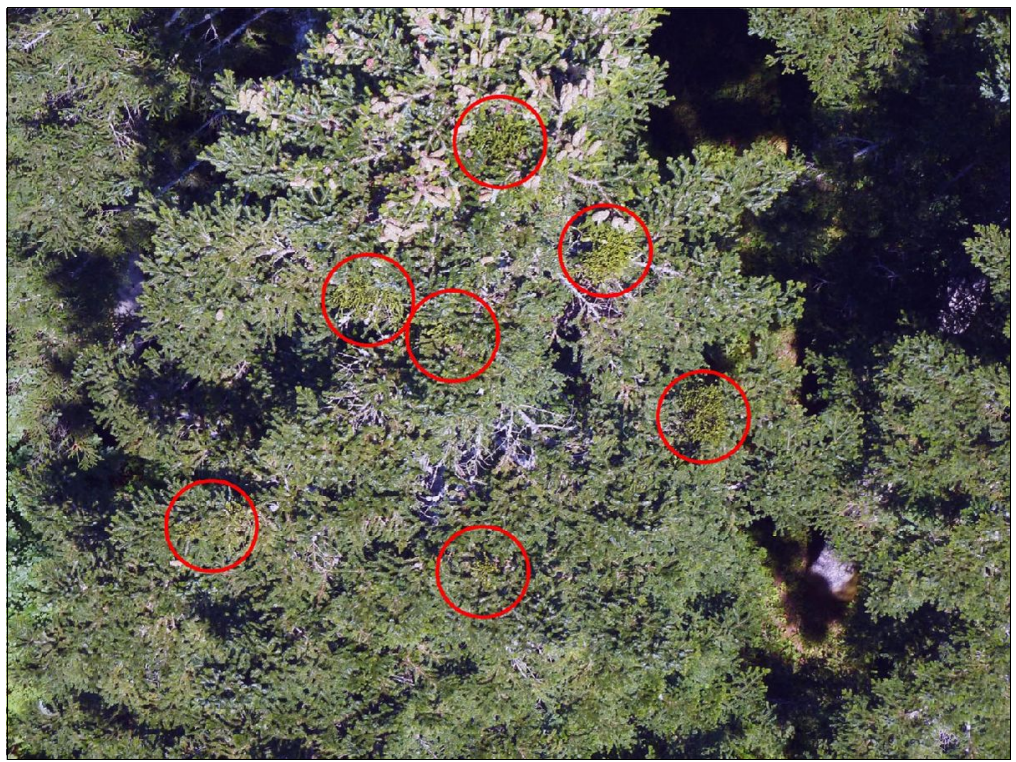

Fig. 10 - Aerial photograph of the recording site taken at an altitude of approx. $30 \mathrm{~m}$. Red circles indicate the position of mistletoe bushes on the silver fir crowns. tions showed that NS- and DF-curves did fairly overlap, while the ODF spectral curve diverged in the visible part of the spectrum over the range $455-650 \mathrm{~nm}$ (Fig. $9 \mathrm{~b}$ ).

Finally, data collected from the flight with the unmanned aerial vehicle at $\sim 30 \mathrm{~m}$ fully supported the spatial distribution of mistletoe-infected silver fir trees drawn by the SAM classification with $5^{\circ}$ threshold value, therefore confirming that a clear identification of mistletoe bushes in fir crowns using hyperspectral images is precisely feasible (Fig. 10). Accordingly, we recommend the use of hyperspectral images and the SAM classification (threshold: $5^{\circ}$ ) as a reliable method for mistletoe detection on fir.

Future research are needed to corroborate the approach used here and to extend its validity to other site/ecosystems. However, the method applied has several advantages over the standard field methods, that imply felling a large numbers of trees and expensive field work (Diminić et al. 2011). Hyperspectral image analysis allows a rapid and economic detection of mistletoe over large areas. Moreover, early detection of infestation hotbeds is fundamental in both commercial forest harvesting (reducing losses in roundwood value caused by mistletoe infestation) and forest protection.

\section{Conclusions}

An assessment of mistletoe infection on silver fir was conducted in two beech-fir forests in the Dinaric region of Croatia by the use of hyperspectral images and supervised classification methods. The following conclusions were made:

1. Mistletoe attacks can be successfully detected by hyperspectral images. The best classification method for detection was Spectral Angle Mapper (SAM) classification with $5^{\circ}$ threshold value.

2. Limitations of standard field methods currently in use call for new approaches based on remote-sensed hyperspectral images to assess fir damage and detect mistletoe.

3 . The methods used here may allow a costeffective mapping of the distribution and intensity of mistletoe infection in silver fir, and can be considered an helpful tool for forest management and planning, forest protection and harvesting.

\section{References}

Aspinall RJ, Marcus WA, Boardman JW (2002). Considerations in collecting, processing and analysing high spatial resolution hyperspectral data for environmental investigations. Journal of Geographical Systems 4: 15-29. - doi: 10.1007/s10 1090100071

Atzberger C, Werner W (1998). Needle reflectance of healthy and diseased Spruce stands. In: Proceedings of the " $1^{\text {st }}$ EARSeL workshop on imaging spectroscopy". Remote Sensing Laboratories, University of Zurich, Switzerland, pp. 
271-283.

Bajić M, Gold H, Božičković K (2008). Application of the airborne remote sensing methods in the humanitarian countermine action (Croatian orig.). In: "Marked the $10^{\text {th }}$ Anniversary of HCRCTRO Scientific Council" (Knapp V ed). Croatian Mine Action Centre, Centre for Testing, Development and Training, Zagreb, Croatia, pp. 4188.

Barbu C (2009). Impact of mistletoe attack (Viscum album ssp. abietis) on radial growth of silver fir. A case study in the north of eastern Carpathians. Annals of Forest Research 52: 8996. [online] URL: http://www.editurasilvica.ro/ afr/52/1/08_Barbu.pdf

Cervera JM, Villaescusa R (1977). Inventario de los abetares del Valle de Arán afectados por el muérdago. Boletín de la Estación Central de Ecología 6: 41-48.

Chéret V, Dagnac J, Fromard F (1987). Le dépérissement du sapin dans les Pyrénées luchonnaises. Revue Forestière Française 39: 12 24. - doi: 10.4267/2042/25756

Cho MA, Debba P, Mutanga O, Dudeni-Tlhone N, Magadla T, Khuluse SA (2012). Potential utility of the spectral red-edge region of Sumbandila sat imagery for assessing indigenous forest structure and health. International Journa of Applied Earth Observation and Geoinformation 16: 85-93. - doi: 10.1016/j.jag.2011.12.005

CROMAC ARC team (2002). Trial II Evaluation Report. Deliverable D15, Report Version: 2.0.0, Airborne Minefeld Area Reduction - ARC, European Commission project 2001-2003, IST2000-25300, European Commission, Brussels, Belgium, pp. 83 .

De Carvalho OA, Meneses PR (2000). Spectral correlation mapper (SCM); an improvement on the spectral angle mapper (SAM). In: Summaries of the "9" JPL Airborne Earth Science Workshop". JPL Publication 00-18, Pasadena, CA, USA, pp. 9.

Diminić D, Potočić N, Jazbec A, Zupanić M (2011). Infestation of common mistletoe and nutrition status of silver fir in Gorski Kotar (Croatia). Croatian Journal of Forest Engineering 32 (1): $223-237$.

Ehleringer JR, Cook S, Tieszen LL (1986). Comparative water use and nitrogen relationships in the mistletoe and its hosts. Oecologia 68: 279284. - doi: 10.1007/BF00384800

Entcheva-Campbell PK, Rock BN, Martin ME, Neefus CD, Irons JR, Middletin EM, Albrechtova $J$ (2004). Detection of initial damage in Norway spruce canopies using hyperspectral airborne data. International Journal of Remote Sensing 24: 5557-5583. - doi: 10.1080/0143116 0410001726058

Fisher JT (1983). Water relations of mistletoe and their hosts. In: "The biology of mistletoe" (Calder M, Bernhardt P eds). Academic Press, Sidney, Australia, pp. 161-184

Girouard G, Bannari A, El Harti A, Desrochers A (2004). Validated spectral angle mapper algorithm for geological mapping: comparative study between Quickbird and Landsat-TM. In:
Proceedings of the "XX ISPRS Conference" (Altan O ed). Istanbul (Turkey) 12-23 July 2004, International Society for Photogrammetry and Remote Sensing, pp. 599-604. [online] URL: http://www.isprs.org/proceedings/XXXV/congress/comm4/papers/432.pdf

Hofstetter M (1988). Über die Verbreitung der Mistel in der Schweiz. Schweiz Z Forstwes 139 (2): 97-127.

Idžojtić M, Pernar R, Kauzlarić Z, Abramović M, Janković D, Pleše M (2003). Intensity of infestation of silver fir (Abies alba Mill.) with mistletoe (Viscum album L. ssp. abietis (Wiesb.) Abrom.) on the area of the forest administration Delnice (Croatian orig.). Forestry Journal 127 (11-12): 545-559.

Idžojtić M, Glavaš M, Zebec M, Pernar M, Dasović M, Pavlus M (2005). Infestation of silver fir (Abies alba Mill.) with mistletoe (Viscum album L. ssp. abietis (Wiesb.) Abrom.) in Croatia (Croatian orig.). Forestry Journal 129 (11-12): 559-573.

Idžojtić M, Pernar R, Glavaš M, Zebec M, Diminić D (2008). The incidence of mistletoe (Viscum album L. ssp. abietis (Wiesb.) Abrom.) on silver fir (Abies alba Mill.) in Croatia. Biologia 63 (1): 81-85. - doi: 10.2478/s11756-008-0014-2

Klepac D (1955). Influence du gui sur l'accroissement des sapinières (Croatian orig.). Forestry Journal 79 (11-12): 231-244.

Kruse FA, Boardman JW, Lefkoff AB, Heidebrecht KB, Shapiro AT, Barloon PJ, Goetz AFH (1993). The spectral image processing system (SIPS) - Interactive visualization and analysis of imaging spectrometer data. Remote Sensing of Environment 44: 145-163. - doi: 10.1016/00344257(93)90013-N

Lamont B (1983). Mineral nutrition of the mistletoes. In: "The Biology of Mistletoe" (Calder M, Bernhardt P eds). Academic Press, Sidney, Australia, pp. 185-204.

Moorthy I, Miller J, Noland TL (2008). Estimating chlorophyll concentration in conifer needles with hyperspectral data: an assessment at the needle and canopy level. Remote Sensing of Environment 112: 2824-2838. - doi: 10.1016/j.rse. 2008.01.013

Noetzli KP, Müller B, Sieber TN (2003). Impact of population dynamics of white mistletoe (Viscum album ssp. abietis) on European silver fir (Abies alba). Annals of Forest Science 60(8): 773-779. - doi: 10.1051/forest:2003072

Olivia J, Colinas C (2007). Decline of silver fir (Abies alba Mill.) stands in Spanish Pyrenees: role of management, hystoric dynamics and pathogens. Forest Ecology and Management 252: 84-97. - doi: 10.1016/j.foreco.2007.06.017

Pernar R (1997). Application of results of aerial photograph interpretation and geographical information system for planning in forestry. Annales experimentatis silvarum culturae provehendis, Universitas studiorum Zagrebiensis 34 : 141-189.

Pernar R, Ančić M, Seletković A (2007a). Application of colour infrared aerial photographs for the assessment of forest damage in the Gospić forest administration (Croatian orig.). Forestry Journal 131 (11-12): 507-522.

Pernar R, Bajić M, Ančić M, Seletković A, Idžojtić M (2007b). Detection of misteletoe in digital colour infrared images of infested fir trees. Periodicum biologorum 109 (1): 67-75.

Plagnat F, Brossier J (1969). Silver fir stands with mistletoe. Silviculture of infested fir stands. Tentative conclusions. Thoughts on fir mistletoe. Revue Forestiere Française 26: 553-561. - doi: 10.4267/2042/20295

Potočić N, Seletković I, Ugarković D, Jazbec A, Mikac S (2008). The influence of climate properties on crown condition of Common beech (Fagus sylvatica L.) and Silver fir (Abies alba Mill.) on Velebit. Periodicum Biologorum 110 (2): 145-150

Prpić B, Seletković Z (2001). Ecological constitution of the Silver fir (Croatian orig.). In: "Silver fir (Abies alba Mill.) in Croatia" (Vukelić J, Gračan J, Dundović J eds). Academy of Forestry Sciences, Zagreb, Croatia, pp. 255-276.

Rowan LC, Mars JC (2003). Lithologic mapping in the Mountain Pass, California area using Advanced Spaceborn Thermal Emission and Reflection Radiometer (ASTER) data. Remote Sensing of Environment 84: 250-266. - doi: 10.1016 /S0034-4257(02)00127-X

Shaw G, Manolakis D (2002). Signal processing for hyperspectral image exploitation. IEEE Signal Processing Magazine 19: 12-16. - doi: 10.11 09/79.974715

Smith KL, Steven MD, Colls JJ (2004). Use of hyperspectral derivative ratios in the red-edge region to identify plant stress responses to gas leaks. Remote Sensing of Environment 92: 207217. - doi: 10.1016/j.rse.2004.06.002

Somers B, Verbesselt J, Ampea E M, Sims N, Verstraetena W W, Coppina P (2010). Spectral mixture analysis to monitor defoliation in mixedaged Eucalyptus globulus Labill plantations in southern Australia using Landsat 5-TM and EO1 Hyperion data. International Journal of Applied Earth Observation and Geoinformation 12: 270277. - doi: 10.1016/j.jag.2010.03.005

StatSoft (2006). Statistica (v. 7.1). Data analysis software system, Tulsa, OK, USA. [online] URL: http://www.statsoft.com

Tsopelas P, Angelopoulos A, Economou A, Souilioti N (2004). Mistletoe (Viscum album) in the fir forest of Mount Parnis, Greece. Forest Ecology and Management 2002: 59-65. - doi: 10.1016/j.foreco.2004.06.032

Uščuplić M (1992). Influence of forest management on the occurrence of silver fir mistletoe (Viscum album L.). University of Belgrade, Bulletin of the Faculty of forestry 74: 7-18.

Uščuplić M, Dautbašić M (1998). Diseases and pests that threats forest ecosystems in Bosnia and Herzegovina (Bosnian orig.). Works of the Faculty of Forestry University of Sarajevo 1: 19-26.

Van der Meer F, Vasquez-Torres M, Van Dijk PM (1997). Spectral characterization of ophiolite lithologies in the troodos ophiolite complex of Cyprus and its potential in prospecting for massive sulphide deposits. International Journal 
of Remote Sensing 18 (6): 1245-1257. - doi: 10.1080/014311697218395

Wang Q, Li P (2012). Hyperspectral indices for estimating leaf biochemical properties in temperate deciduous forests: Comparison of simulated and measured reflectance data sets. Ecological
Indicators 14: 56-65. - doi: 10.1016/j.ecolind. 2011.08.021

Watson DM (2001). Mistletoe - a keystone resource in forests and woodlands worldwide. Annual Review of Ecology and Systematics 32: 219-249. - doi: 10.1146/annurev.ecolsys.32.0815
01.114024

Zuber R (1983). Forstschutz. In: "Wald- und Forstwirtschaft in Graubünden". Ründerwald, Beiheft 12, pp. 115-119. 